\title{
Investigations into the Potential Role of Metabolites on the Anti-Leukemic Activity of Imatinib, Nilotinib and Midostaurin
}

\author{
Paul W. Manley* \\ §SISF-SCS Distinguished Investigator Award 2018
}

\begin{abstract}
The efficacy and side-effects of drugs do not just reflect the biochemical and pharmacodynamic properties of the parent compound, but often comprise of cooperative effects between the properties of the parent and active metabolites. Metabolites of imatinib, nilotinib and midostaurin have been synthesised and evaluated in assays to compare their properties as protein kinase inhibitors with the parent drugs. The $\mathrm{N}$-desmethylmetabolite of imatinib is substantially less active than imatinib as a BCR-ABL1 kinase inhibitor, thus providing an explanation as to why patients producing high levels of this metabolite show a relatively low response rate in chronic myeloid leukaemia (CML) treatment. The hydroxymethylphenyl and $N$-oxide metabolites of imatinib and nilotinib are only weakly active as BCR-ABL1 inhibitors and are unlikely to play a role in the efficacy of either drug in CML. The 3-(R)-HO-metabolite of midostaurin shows appreciable accumulation following chronic drug administration and, in addition to mutant forms of FLT3, potently inhibits the PDPK1 and VEGFR2 kinases $\left(\mathrm{IC}_{50}\right.$ values $<100 \mathrm{nM}$ ), suggesting that it might contribute to drug efficacy in acute myeloid leukaemia patients. The case studies discussed here provide further examples of how the synthesis and characterisation of metabolites can make important contributions to understanding the clinical efficacy of drugs.
\end{abstract}

Keywords: Imatinib · Leukaemia · Metabolite · Midostaurin · Nilotinib

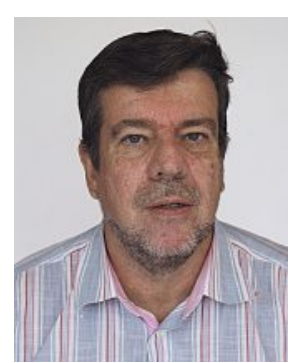

Paul Manley received his doctorate in organic chemistry from Liverpool University in 1979 and has 40 years of pharmaceutical industry medicinal chemistry experience. Notable achievements include the discovery of nilotinib (Tasigna ${ }^{\circledR}$ ) and asciminib as treatments of chronic myelogenous leukaemia, as well as identifying the potential of midostaurin $\left(\right.$ Rydapt $\left.^{\circledR}\right)$ for acute myelogenous leukaemia. He has co-authored over 130 publications and is co-inventor of over 70 patents. In 2012 he was honoured by American Chemical Society as a Hero of Chemistry, he received an Edison Patent award in 2013 and in 2018 was honoured with a Distinguished Investigator Award from the Swiss Chemical Society.

\section{Introduction}

Although several authors have reviewed the topic of active drug metabolites and extolled the importance of evaluating their contribution to the efficacy and side effects of the parent drugs, ${ }^{[1-4]}$ this is not frequently addressed either in preclinical publications on drug candidates or when clinical data is reported. When the exposure of a human metabolite represents $>10 \%$ of total drug-related exposure, safety concerns can warrant its non-clinical characterisation to assess safety before large numbers of subjects are exposed to the drug, ${ }^{[5]}$ but this does not focus on contributions to efficacy or low grade adverse events and the findings might not be published.

${ }^{\star}$ Correspondence: Dr. P. W. Manley

E-mail: paul.manley@novartis.com, Global Discovery Chemistry,

Novartis Institutes for Biomedical Research, Novartis Pharma AG, CH-4002 Basel
An important physiological role of biotransformations is to facilitate the clearance of xenobiotics from the circulation. Biotransformations of medicinal drugs usually generate metabolites having increased hydrophilicity and topological polar surface area (tPSA), which as well as enhancing clearance, often reduce membrane penetration of target tissues. Consequently the formation of substantial amounts of metabolites, regardless of their intrinsic activity, can reduce drug efficacy. However, not all metabolites are rapidly cleared and whereas biotransformations can generate metabolites which maintain the intrinsic beneficial pharmacological activity of the parent drug towards the target, metabolites might have different activities to the parent, or have a combination of the parent drug's activity and that relating to additional targets. In fact it has been reported that metabolites play a significant role in the clinical efficacy of many prescribed drugs. ${ }^{[4]}$

Knowing the mechanism of action of a drug at the molecular level can help to assess how metabolic changes might impact the pharmacological effects exerted by metabolites. Biotransformations that lead to the fragmentation of large portions of the molecules leading to the removal of pharmacophore elements usually result in reduced activity, as can be the case with amidase-mediated cleavage of amides and heteroatom dealkylations. The potential effects of $\mathrm{N}$ - or $\mathrm{S}$-oxide formation, either as a result of loss of hydrogen bonding capability or the introduction of polarity, are also often predictable. On the other hand the loss of small alkyl groups and the effects of hydroxylation in biotransformations are not easy to anticipate and although these may increase affinity towards the target, the need for additional desolvation can counter any energy gains.

Based upon the above considerations, in order to assess whether a metabolite contributes to the overall pharmacology of the parent drug, it is critical to quantify its potency against its phar- 
macological targets and balance this with its pharmacodynamic and pharmacokinetic properties. This can then be of value in dose selection and scheduling in clinical trials, as well as in interpreting the efficacy and adverse events observed in patients. The blood and the highly perfused bone marrow are the usual target organs for drugs to treat leukaemias, so once a metabolite achieves an adequate concentration in the circulation it should be accessible to the leukemic cells and therefore in vitro cellular activity should translate into in vivo effects. The three case studies of antileukemic drugs discussed below provide examples where metabolism can reduce efficacy in patients (imatinib), where it has little effect on efficacy (nilotinib) and where it can increase efficacy though increased intrinsic activity or through polypharmacology (midostaurin).

\section{Imatinib}

\subsection{Imatinib as a Tyrosine Kinase Inhibitor for the Treatment of CML}

Imatinib $\left(1\right.$; Glivec $\left.^{\circledR}\right)$ heralded the start of the era of genomically targeted anti-cancer drugs. ${ }^{[6]}$ This drug is a very potent inhibitor of the tyrosine kinase activity associated with the discoidin domain (DDR-1 and -2), platelet-derived growth factor (PDGFR-A and $-\mathrm{B}$ ) and the stem cell factor (KIT) receptors, however it is best known as an inhibitor of the Abelson kinase (ABL1) activity of the chimeric BCR-ABL1 oncoprotein. ${ }^{[7]}$ The latter activity underlies the efficacy of imatinib as a therapy for chronic myeloid leukaemia (CML), which when adequately treated has now been transformed into a chronic disease. ${ }^{[8]}$

Following ground-breaking findings from the Kuriyan group, ${ }^{[9]}$ it has been established that imatinib inhibits the kinase activity of ABL1 by binding in a so-called 'type-2' fashion to a 'DFG-out' catalytically inactive conformation of the kinase domain, thereby preventing ATP from binding. ${ }^{\left[{ }^{-12}\right]}$ The imatinib-ABL1 complex is stabilised by a large number of van der Waal's contacts which play a major part in driving the binding energy, supplemented by an array of hydrogen bonds that define the geometry of the interactions. The latter involve the pyridine-N and backbone-NH of Met318, the aminopyrimidine and side-chain hydroxyl of Thr315, the amide-NH and side-chain carboxylate of Glu286, the amide-carbonyl and backbone-NH of Asp381, together with the protonated methylpiperazine with the backbone-carbonyl atoms of Ile360 and His361 (Fig. 1a). In addition, a pyrimidine-N atom of imatinib makes a strong interaction with a water molecule, whose position is probably favoured by stacking face-on to the methylphenyl group, together with additional hydrogen bonds to other well-defined water molecules. Based upon this binding mode, one would predict that structural modifications that interfered with the van der Waal's contacts or which impeded the hydrogen-bonding capability of imatinib, would reduce the binding affinity.

\subsection{Identification of Metabolites of Imatinib}

Following once-daily oral administration of $400 \mathrm{mg}$ of Glivec $^{\circledR}$ (the $\beta$-crystalline methanesulphonate salt form of the compound) to CML patients, imatinib is highly absorbed (absolute bioavailability 98\%) and attains mean steady-state plasma trough levels $\left(\mathrm{C}_{\text {min }}\right)$ of $1.98 \mu \mathrm{M} .{ }^{[13]}$ Imatinib clearance is primarily through cytochrome P450 (CYP) $3 \mathrm{~A} 4 / 5$ and 2C8 enzyme-mediated metabolism in the liver, with most of the metabolites being excreted in the faeces. ${ }^{[14,15]}$ After administration of a single oral dose of $\left[{ }^{14} \mathrm{C}\right]$-imatinib methanesulphonate $(239 \mathrm{mg})$ to healthy volunteers, excretion was slow with $26.7 \%$ of the total radioactivity recovered after 2 days and $80.2 \%$ after 7 days. ${ }^{[16]}$ The predominant route of elimination was faecal, with $66.9 \%$ and $13.2 \%$ of the dose recovered in the faeces and urine respectively within 7 days; unchanged imatinib accounted for $25 \%$ of the dose (20\% in faeces and $13 \%$ in urine).

The structures of the metabolites (Fig. 2) were tentatively assigned by mass spectrometry fragmentation, ${ }^{[16]}$ and subsequently confirmed by comparison with analytically pure, authentic samples obtained from total synthesis, with the structures being unequivocally assigned by NMR spectroscopy. Oxidation of imatinib with either $m$-chloroperoxybenzoic acid (MCPBA) or hydrogen peroxide readily afforded samples of the 1-oxido- $(3)^{[17]}$ and 1,4-dioxido- $N$-methylpiperazine (4) ${ }^{[18]}$ metabolites respectively. ${ }^{[19]}$ The pyridine- $N$-oxide (2) ${ }^{[20]}$ was prepared by MCPBA oxidation of the imatinib analogue (10), ${ }^{[21]}$ followed by amide hydrolysis, coupling of the resulting aniline with chloromethylbenzoyl chloride and then reaction with $N$-methlypiperazine (Scheme 1). ${ }^{[19]}$

The metabolites resulting from $N$-demethylation (7) and carbon-oxidation of either the methylpiperazine (6) or desmethylpiperazine $(\mathbf{8})^{[23]}$ were prepared as described previously. ${ }^{[19,22]}$ The hydroxymethyl metabolite (5) was synthesised according to the route outlined in Scheme 2: Borane reduction of 4-nitroanthranilic acid afforded the alcohol, which was protected as the allyl ether. This withstood acid-catalysed condensation with cyanamide to give the guanidine, followed by condensation with the requisite vinylogous amide, to afford the pyridylpyrimidine. Cleavage of the allyl group then gave the alcohol, allowing re-
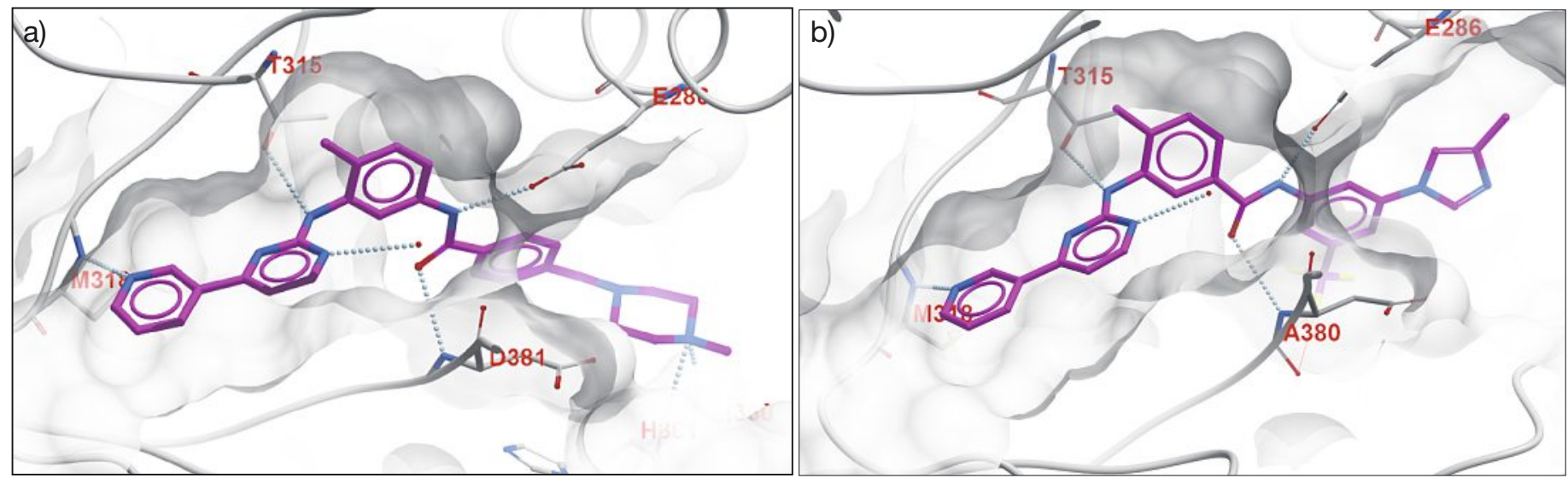

Fig. 1. Representations of the crystallographic binding modes of imatinib (1; protein database, PDB entry: $2 \mathrm{HYY})^{[1]}$ and nilotinib (11; PDB entry: $3 \mathrm{CS9})^{[30]}$ to the catalytic domain of ABL1 kinase. Protein surfaces are coloured in grey with key amino-acid side-chains picked out and labelled; carbon atoms of ligands are coloured magenta, with nitrogen and oxygen atoms of ligands and key amino acid side-chains shown in blue and red respectively; hydrogen bonds are indicated by dotted lines and water molecules are shown as red spheres. Both ligands bind to very similar conformations of the protein, with the key interactions made by imatinib and nilotinib shown in Fig. 1a and b respectively. With nilotinib, in addition to the hydrogen bond to the $\mathrm{A} 380$ backbone $\mathrm{NH}$, the CF3 group makes an electrostatic interaction with the A380 backbone carbonyl (see Fig. 3). 

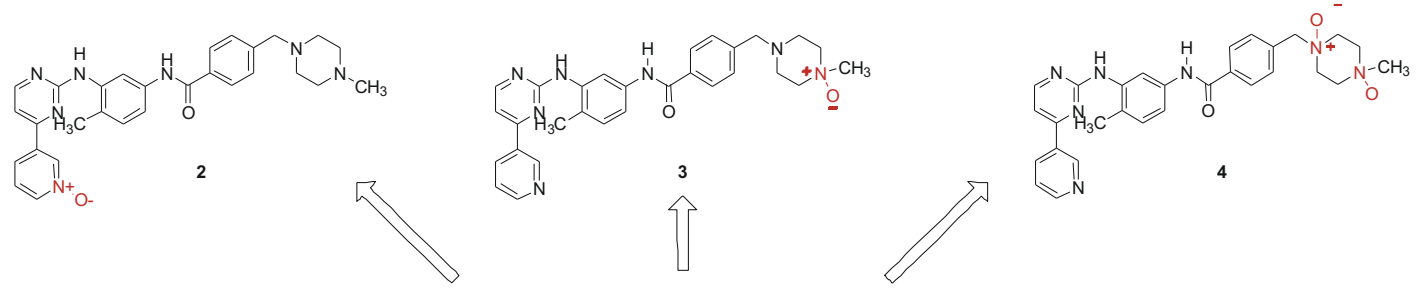<smiles>Cc1ccc(N)cc1Nc1nccc(-c2cccnc2)n1</smiles><smiles>[C]#[C]</smiles><smiles>Cc1ccc(NC(=O)c2ccc(CN3CCN(C)CC3)cc2)cc1Nc1nccc(-c2cccnc2)n1</smiles><smiles>C1=CCCC=C1</smiles><smiles>CN1CCN(Cc2ccc(C(=O)Nc3ccc(O)c(Nc4nccc(-c5cccnc5)n4)c3)cc2)CC1</smiles><smiles>c1ccccc1</smiles><smiles>Cc1ccc(NC(=O)c2ccc(CN3CCN(C)C(=O)C3)cc2)cc1Nc1ncccc1-c1cccnc1</smiles>
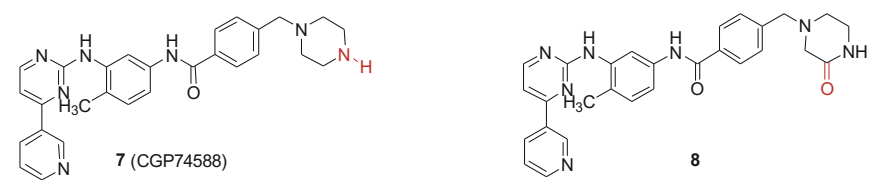

Fig. 2. The main metabolites of imatinib detected in humans. Structures were proposed based upon liquid chromatography - tandem mass spectrometry (LC-MS/MS) fragmentation and validated by comparison with authentic standards. The position of the $\left[{ }^{14} \mathrm{C}\right]-$ label in imatinib used for human adsorption and metabolism studies is indicated by an asterisk. The dashed arrow leading to 9 indicates that this metabolite, although found in mouse, was not detected in human.
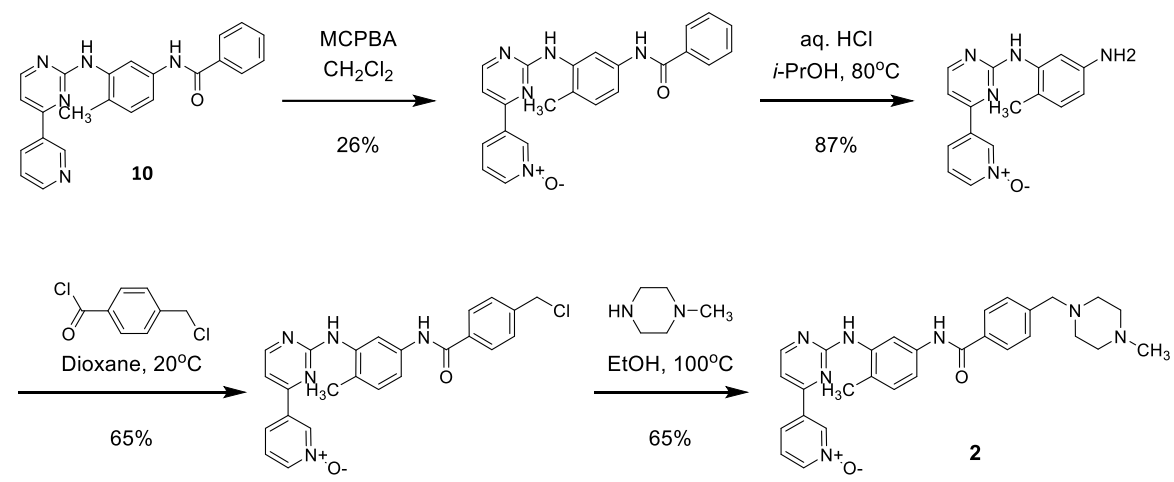

Scheme 1. Synthetic route employed to prepare an authentic sample of the imatinib pyridine- $N$-oxide metabolite $2 .{ }^{[20]}$

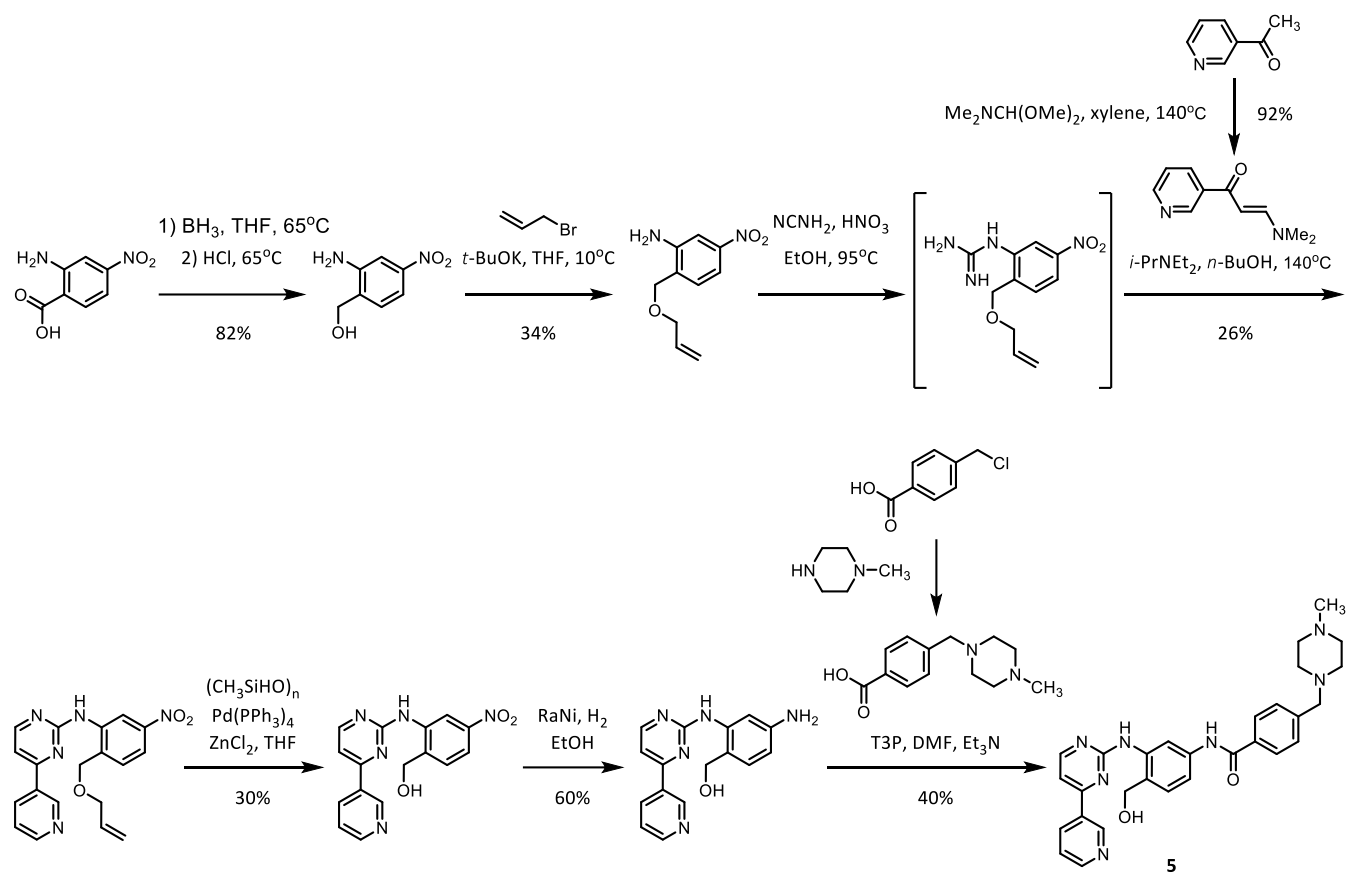

Scheme 2. Synthetic route employed to prepare an authentic sample of the imatinib hydroxymethyl metabolite $5 .^{[24]}$ 
duction of the nitro group and amidation of the resulting aniline to provide 5. [24]

Although the amidolysis product 9 was a major metabolite in mouse and a minor metabolite in rat, neither this mutagenic phenylenediamine nor any derivatives resulting from it undergoing Phase II metabolic conjugations were detected as human metabolites. ${ }^{[25]}$

With most of the metabolites unambiguously characterised and their amounts quantified, it was possible to assess their potential contribution to drug efficacy in CML patients.

\subsection{Effects of Imatinib Metabolites on BCR-ABL1 Kinase and their Potential Contribution to Drug Efficacy in CML Patients}

Simple direct comparisons of the effects of compounds on the kinase activity of ABL1 constructs in biochemical assays are often unreliable because differences in binding modes and binding kinetics are incongruous with the use of standard assay conditions. ${ }^{[26]}$ A pragmatic solution to this, although it discounts differences in cell permeability, is to compare effects on BCRABL1 autophosphorylation either in CML-derived cell lines or in haematopoietic cells, such as the murine IL-3-dependent myeloid 32D cell line transfected to express the oncoprotein. An appropriate capture enzyme-linked immunosorbent assay (ELISA) using murine 32D cells was developed by Jürgen Mestan. ${ }^{[27,28]}$ The effects of imatinib and its major metabolites in this assay are presented in Table 1.

Table 1. Comparison of inhibitory concentrations (mean $I_{50}$ values \pm SEM; $n M$ ) of imatinib and nilotinib with those of their metabolites on BCR-ABL1 autophosphorylation in murine 32D haematopoietic cells transfected to express BCR-ABL1.

\begin{tabular}{|c|c|c|c|} 
Compound & $\mathbf{I C}_{\mathbf{5 0}}[\mathbf{n M}]$ & Compound & $\mathbf{I C}_{\mathbf{5 0}}[\mathbf{n M}]$ \\
\hline Imatinib (1) & $192 \pm 6$ & Nilotinib (11) & $19 \pm 1$ \\
\hline $\mathbf{2}$ & $>3000$ & $\mathbf{1 2}$ & $>3000$ \\
\hline $\mathbf{3}$ & $>3000$ & $\mathbf{1 3}$ & $>3000$ \\
\hline $\mathbf{4}$ & $>10000$ & $\mathbf{1 4}$ & $>10000$ \\
\hline $\mathbf{5}$ & $>5000$ & $\mathbf{1 5}$ & $256 \pm 54$ \\
\hline $\mathbf{6}$ & $>3000$ & $\mathbf{1 6}$ & $19 \pm 2$ \\
\hline $\mathbf{7}$ & $512 \pm 93$ & $\mathbf{1 7}$ & $>3000$ \\
\hline $\mathbf{8}$ & $3750(\mathrm{n}=2)$ & $\mathbf{1 8}$ & $39 \pm 3$ \\
\hline $\mathbf{9}$ & $>10000$ & $\mathbf{1 9}$ & $>3000$ \\
\hline & & $\mathbf{2 1}$ & $>3000$ \\
\hline
\end{tabular}

aAlthough not a metabolite, the methylester (22; Scheme 6) was also tested and found to have a mean $\mathrm{IC}_{50}$ value of $149 \pm 19 \mathrm{nM}$. Since intracellular ester cleavage is likely to be rapid, this suggests that poor intracellular penetration contributed to the weak activity of 17 .

The main circulating metabolite of imatinib in man is the $N$-demethylated piperazine 7 (CGP74588), concentrations of which can reach $1.7 \mu \mathrm{M}$ following once-daily administration of $400 \mathrm{mg}$ of the drug to CML patients. ${ }^{[13]} \mathrm{N}$-Dealkylation of amines is a frequently encountered metabolic transformation, ${ }^{[1]}$ and in the case of tyrosine kinase inhibitors can result in highly active metabolites, as for example the $N$-desethyl metabolite of sunitinib. ${ }^{[29]}$ In the case of imatinib, initial reports suggested that 7 had similar potency as the parent drug against BCR-ABL1, however characterisation of this metabolite established that it is $\approx 3$-fold less active (Table 1). ${ }^{[22]}$ Most importantly, this lack of activity can explain the observation that CML patients producing high levels of 7 frequently have inferior responses to those patients who demethylate imatinib less efficiently, which is a finding that might support a decision to change therapy.

After single dose, oral administration of $\left[{ }^{14} \mathrm{C}\right]$-imatinib methanesulphonate $(239 \mathrm{mg}$ ) the main metabolite was 7 and only small amounts of the other metabolites were detected in plasma (exposure expressed as total area under the plasma drug concentration-time curve, $\mathrm{AUC}_{0-24 \mathrm{~h}}(\mu \mathrm{mol} \cdot \mathrm{h} / \mathrm{L})$ and percentage of total $\left[{ }^{14} \mathrm{C}\right]$ $\left.\mathrm{AUC}_{0-24 \mathrm{hr}}\right)$ : imatinib (17.7; $\left.70 \%\right), 7$ (2.4; $\left.9.5 \%\right), 6(0.32 ; 1.2 \%)$, $2(0.29 ; 1.1 \%), 5$ (because of co-eluting trace metabolite $<0.22$; $<0.9 \%), \mathbf{8}(0.11 ; 0.45 \%)$ and $\mathbf{3}$ (because of co-eluting trace metabolite $<0.21 ;<0.8 \%)$. ${ }^{[16]}$ Furthermore, these metabolites show little activity against BCR-ABL1 autophosphorylation (Table 1), as to be expected since the structural changes will interfere with the interactions seen in the crystal structure of the imatinib-ABL1 complex. Consequently, these metabolites are unlikely to play any role in the efficacy of imatinib in CML patients.

\section{Nilotinib}

\subsection{Nilotinib as a Tyrosine Kinase Inhibitor for the Treatment of CML}

Structure-guided medicinal chemistry directed towards finding a drug that would address imatinib-resistance in CML patients culminated in the discovery of nilotinib (11; Tasigna $\left.{ }^{\circledR}\right) .{ }^{[8,11,30]}$ Although nilotinib has similar potency to imatinib towards the DDR, PDGFR and KIT receptor kinases, it is much more potent and hence selective towards ABL1/BCR-ABL1. ${ }^{[7,28]}$ This activity translates into nilotinib being able to combat imatinib resistance in CML patients, as well as it having superior efficacy in newly-diagnosed patients. ${ }^{[8]}$

In addition to being designed to have a much better topological fit to the binding pocket identified from the imatinib-ABL1 crystal structure, nilotinib was constructed to avoid any liability of amide cleavage leading to the formation of the mutagenic phenylenediamine 9 and to have lowered basicity, thus reducing its potential to be a good substrate for cell efflux pump transporters. The crystal structure of nilotinib in complex with human ABL1 kinase confirms that the drug binds in a similar manner to that of imatinib, with the activation-loop adopting a 'DFG-out' inactive conformation. ${ }^{[8,11]}$ Whereas the hydrogen-bond interactions involving the pyridyl-N with the backbone-NH of Met318, the anilino-NH with the side-chain hydroxyl of Thr315, and the pyrimidine- $\mathrm{N}$ atom with the conserved water molecule are observed in both structures, there are some major differences in the other molecular interactions through which the drugs bind (Fig. 1b).

In the case of the amide, which is reversed in nilotinib, there are two hydrogen-bonds involving the amido- $\mathrm{NH}$ with the sidechain carboxylate of Glu286, and the amido- $\mathrm{C}=\mathrm{O}$ with the backbone-NH of Asp381. There are also close contacts between carbon atoms of nilotinib and both the carbonyl group of Met318 and the carboxyl group of Glu286, indicating weak hydrogen-bond interactions. ${ }^{[11]}$ In addition, nilotinib participates in an electrostatic interaction involving a fluorine of the trifluoromethyl group and the polarised carbon of the carbonyl group of Ala380 (Fig. 3). ${ }^{[31]}$ This type of $\mathrm{C}-\mathrm{F}$ to $\mathrm{C}=\mathrm{O}$ interaction has been seen in other protein-ligand complexes, ${ }^{[32]}$ in which the carbonyl bond is perpendicular to the $\mathrm{C}-\mathrm{F}$ bond (F-C-O angle: $90^{\circ}$ ) and the distance between the $\mathrm{F}$ and $\mathrm{C}$ atoms is on average $3.1 \AA$. The average interatomic distance in the four molecules in the asymmetric unit of the nilotinib complex is $3.0 \AA$, with the atoms making the same $90^{\circ}$ angle, indicating that the fluorine interaction contributes favourably to binding. The methylimidazole moiety does not form hydrogen-bonds with the protein, but makes important van der Waals interactions with Glu286, Val289 and Phe359. 


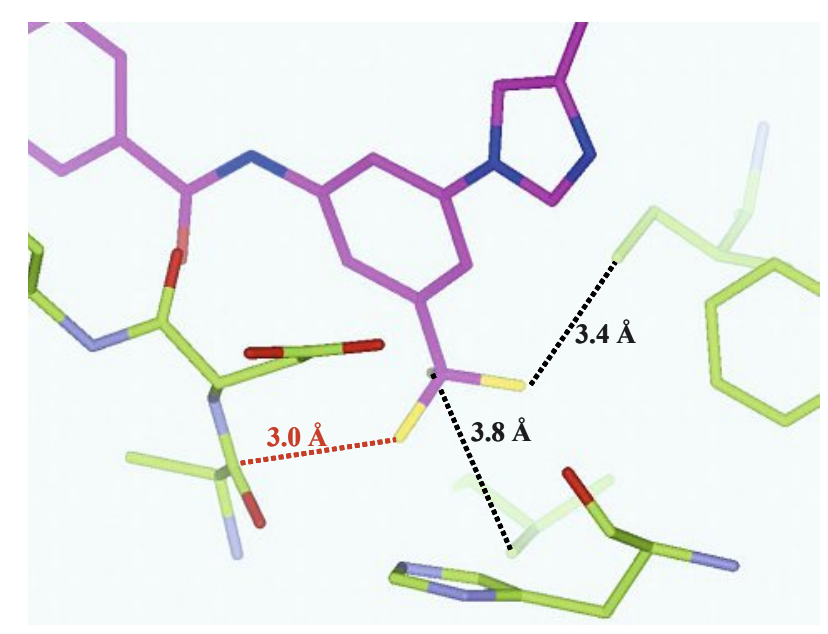

Fig. 3. Representation of the $\mathrm{CF}---\mathrm{C}=\mathrm{O}$ dipolar interaction in the nilotinib-ABL1 cocrystal structure (PDB entry: 3CS9). ${ }^{[30]}$ Carbon, nitrogen and oxygen atoms of the protein are coloured in green, blue and red respectively; carbon, fluorine and nitrogen atoms of nilotinib are coloured magenta, yellow and blue respectively; dotted lines show contact distances. One fluorine atom is in close contact with the backbone- $\mathrm{C}=\mathrm{O}$ of Asp381, with a mean F-C distance of $3.02 \AA$ (4 mols/unit cell: 2.95, 2.97, 3.08 and $3.09 \AA$ ) and a geometry of $90^{\circ}$ (Bürgi-Dunitz angle); the sum of the van der Waals radii of fluorine and carbon is $3.30 \AA$.

\subsection{Identification of Metabolites of Nilotinib}

Nilotinib is poorly soluble in aqueous media and subject to solubility-limited absorption and a positive food effect, which is partially overcome by oral administration of Tasigna (the $\mathrm{HCl}$ salt of the compound) without food at $300 \mathrm{mg}$ twice daily (BID) to newly diagnosed CML patients or $400 \mathrm{mg}$ twice daily to patients resistant or intolerant to prior therapies. ${ }^{[33]}$ The drug is rapidly absorbed and has a terminal elimination half-life, $\mathrm{t}_{1 / 2} \approx 16$ hours, leading to mean steady-state $\mathrm{C}_{\min }$ values of $2.12 \mu \mathrm{M}(300 \mathrm{mg}$ BID) and $2.34 \mu \mathrm{M}(400 \mathrm{mg}$ BID). Following oral administration of a single dose of $\left[{ }^{14} \mathrm{C}\right]$-nilotinib free-base $(2 \times 200 \mathrm{mg}$ capsules; $25 \mu \mathrm{Ci} / \mathrm{mg})$ to fasted, male volunteers, the majority of the radiolabelled dose was excreted in the faeces within 7 days, with neither nilotinib nor any metabolites being detected in the urine. The major circulating component was nilotinib, which accounted for $87.5 \pm 9.2 \%$ of the total area under the plasma drug concentration-time curve $\left(\left[{ }^{14} \mathrm{C}\right]\right.$ $\mathrm{AUC}_{0-24 \mathrm{hr}}$ ). Five primary metabolic pathways, operating alone or in concert, appear to be involved in CYP3A4-mediated oxidative clearance of the drug in man, resulting in the formation of at least 20 minor metabolites (Fig. 4). ${ }^{[34]}$ The structures of the most abundant metabolites were tentatively assigned by LC-MS and confirmed by comparison with authentic samples obtained by total synthesis.

In contrast to imatinib, oxidation of the pyridinyl-pyrimidine moiety of nilotinib led to the formation of several metabolites, which together accounted for the elimination of approximately $7.9 \%$ of the dose. Authentic samples of the two mono- $N$-oxides $\mathbf{1 2}^{[35]}$ and $\mathbf{1 3}{ }^{[36]}$ and the bis- $N$-oxide $\mathbf{1 4}^{[37]}$ were prepared by MCPBA oxidation of the ester $\mathbf{2 0}$ to afford three products, each of which were separated, saponified and subjected to propylphosphonic anhydride (T3P) mediated amide coupling (Scheme 3).

As observed with imatinib, metabolic hydroxylation of the phenyl- $\mathrm{CH}_{3}$ group in nilotinib occurred in humans. An authentic sample of $\mathbf{1 5}^{[38]}$ was prepared by the route shown in Scheme 4. Because neither of the nitrobenzylalcohol intermediates could be converted to their corresponding allyl ethers, $t$-butyldiphenylsilyl protection was employed, which because of its acid sensitivity,

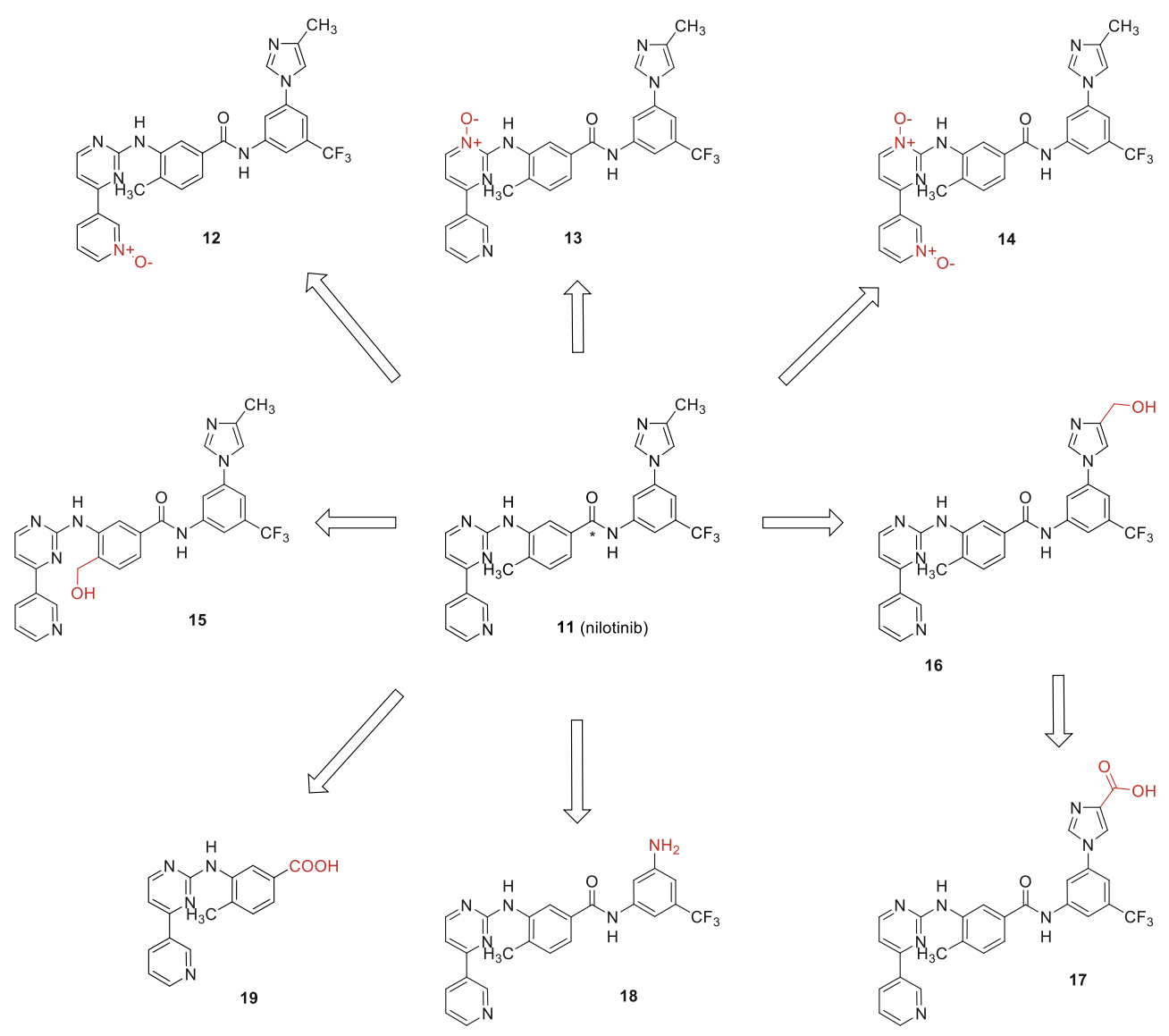

Fig. 4. The main metabolites of nilotinib (11) detected in humans. Structures were proposed based upon liquid chromatography tandem-mass spectrometry LC-MS/MS fragmentation and validated by comparison with authentic standards. The position of the $\left[{ }^{14} \mathrm{C}\right]$-label in nilotinib used for human adsorption and metabolism studies is indicated by an asterisk. 


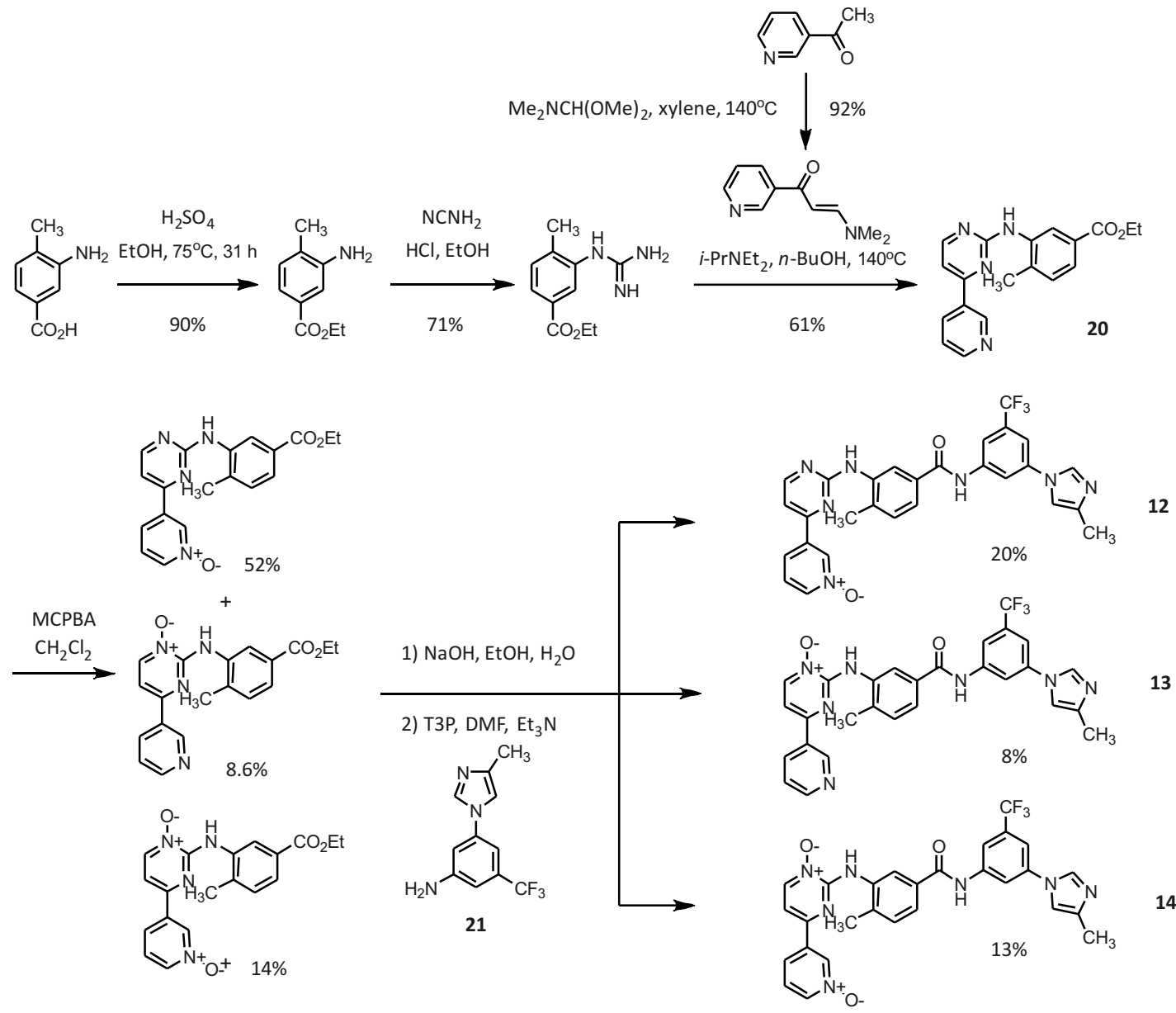

Scheme 3. Synthetic route employed to prepare authentic samples of the nilotinib $N$-oxide metabolites $12,{ }^{[35]}{ }^{13},{ }^{[36]}$ and $14 .{ }^{[37]}$
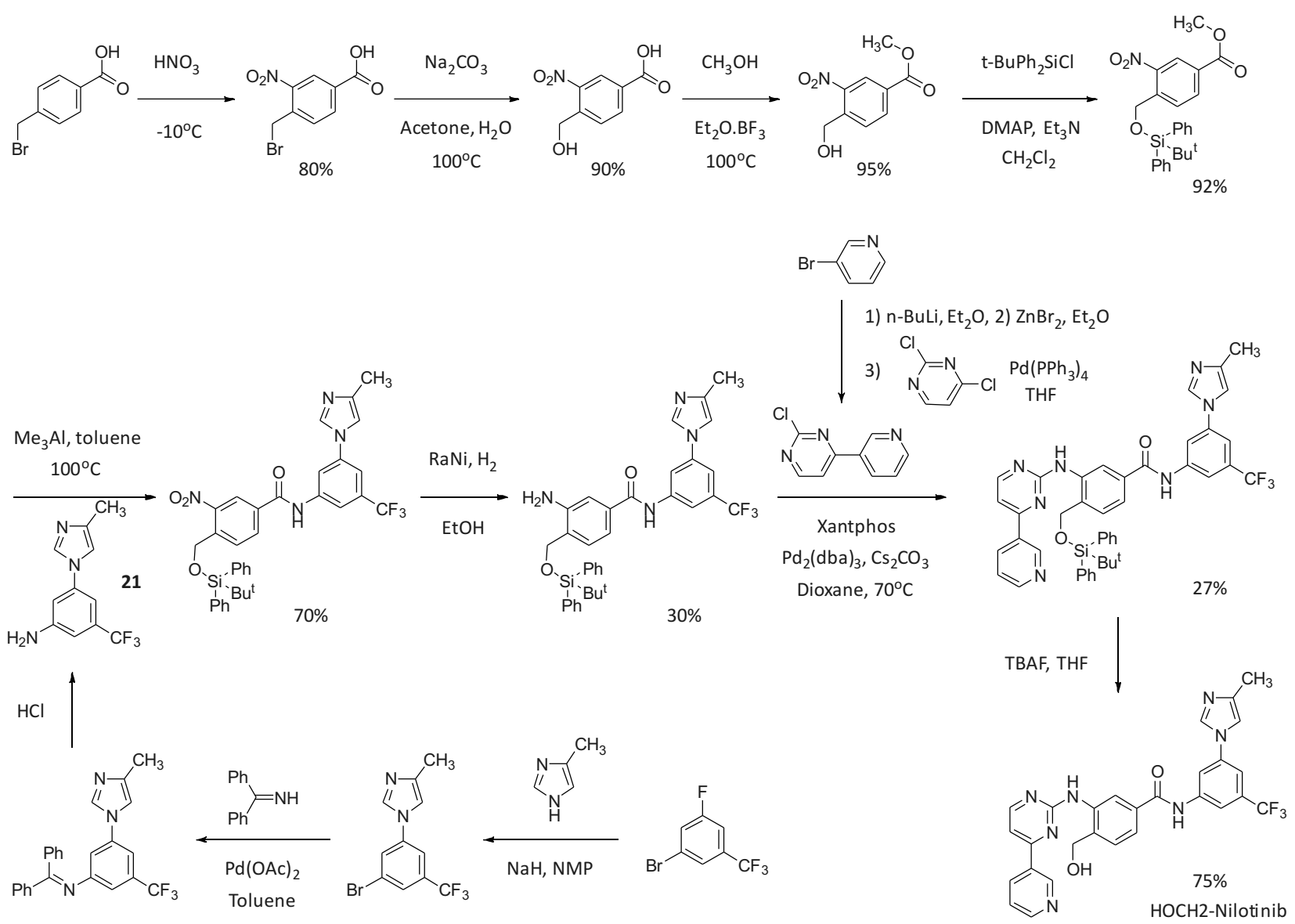

Scheme 4. Synthetic route employed to prepare an authentic sample of the nilotinib hydroxymethylphenyl metabolite $15^{[38]}$ 
necessitated introducing the aminopyrimidine via BuchwaldHartwig amination, in place of the Pinner-type procedure which had been employed to synthesise the imatinib metabolite $\mathbf{5}$ (Scheme 2).

Most of the nilotinib metabolites detected in faeces (representing $\approx 17 \%$ of the radiolabelled dose in healthy volunteers) resulted from hydroxylation followed by oxidation, as well as fragmentation of the methylimidazole moiety. T3P-mediated coupling of the acid $19,{ }^{[39]}$ which was readily prepared by saponification of the ester $\mathbf{2 0}$ (Scheme 3), with 5-(trifluoromethyl)benzene-1,3-diamine afforded the amino metabolite 18. ${ }^{[40]}$ Similar coupling either with the $O$-protected aminophenylimidazole-methanol or with the aminophenylimidazole-carboxylate, followed by deprotection afforded the hydroxymethylimidazole $\mathbf{1 6}^{[41]}$ and imidazolecarboxylic acid $17^{[42]}$ metabolites (Schemes 5 and 6$)$.

Whereas metabolic cleavage of the amide was not found in humans with imatinib, the benzoic acid $\mathbf{1 9}$ was detected in the faeces $(0.18 \%$ of dose) following nilotinib administration. The corresponding aniline $\mathbf{2 1}$ (available from the route shown in Scheme 4), which would not carry the $\left[{ }^{14} \mathrm{C}\right]-$ label, was not detected.

\subsection{Effects of Nilotinib Metabolites on BCR-ABL1 Kinase and their Potential Contribution to Drug Efficacy in CML Patients}

With authentic samples of metabolites available, it was established that following oral administration of a single oral dose of $\left[{ }^{14} \mathrm{C}\right]$-nilotinib to healthy volunteers, ${ }^{[34]}$ only three metabolites were detected in blood serum at $>1 \%$ levels of the nilotin$\mathrm{ib}$ radiochromatogram (percentage of unchanged $\left[{ }^{14} \mathrm{C}\right]$-nilotinib $\left.\mathrm{AUC}_{0-48 \mathrm{hr}}\right): \mathbf{1 7}(6.1 \%), \mathbf{1 6}(4.7 \%)$ and $\mathbf{1 5}(1.3 \%)$. The primary component detected (0-168 hours) in the faeces was unchanged nilotinib representing $68.5 \%$ of the dose, with an additional $21.5 \%$ being distributed between 18 different metabolites. Although the $\mathrm{N}$-oxide 12 was the major metabolite in the faeces (chromatography unresolved $\mathbf{1 2}+\mathbf{1 7}$ representing $8.08 \%$ of the dose), it was only present at low levels $(0.51 \%)$ in serum. Other major metabolites detected in the faeces included $16(4.0 \%)$, the aniline $\mathbf{1 8}$ $(1.4 \%)$ together with its formamide derivative (1.5\%), $\mathbf{1 5}(1.3 \%)$, $13(1.2 \%), 14(0.9 \%)$ and $19(0.2 \%)$

The effects of the metabolites of nilotinib on BCR-ABL1 autophosphorylation are presented in Table 1 . The only compounds having measurable activity were $\mathbf{1 5}\left(\mathrm{IC}_{50} 256 \mathrm{nM}\right), \mathbf{1 6}\left(\mathrm{IC}_{50} 19\right.$ $\mathrm{nM})$ and $18\left(\mathrm{IC}_{50} 39 \mathrm{nM}\right)$. Since none of these were detected at

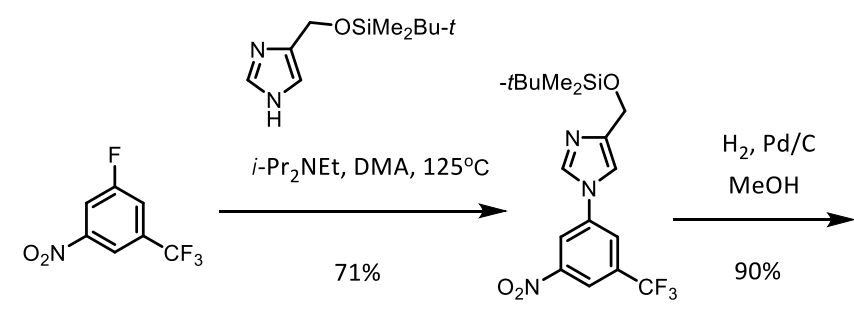<smiles>COCc1cn(-c2cc(N)cc(F)c2)cn1</smiles><smiles>CCCCOCc1cn(-c2cc(NC(=O)c3ccc(C)c(Nc4nccc(-c5cccnc5)n4)c3)cc(C(F)(F)F)c2)cn1</smiles><smiles>Cc1ccc(C(=O)Nc2cc(-n3cnc(CO)c3)cc(C(F)(F)F)c2)cc1Nc1nccc(-c2cccnc2)n1</smiles><smiles>CC(=O)c1c[nH]cn1</smiles>

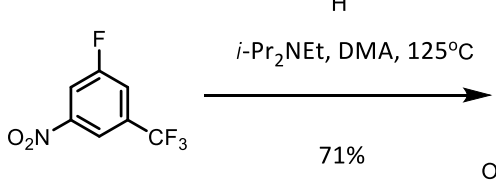<smiles>CC(=O)OCc1cn(-c2cc([N+](=O)[O-])cc(C(F)(F)F)c2)cn1</smiles><smiles>COC(=O)c1cn(-c2cc(N)cc(C(F)(F)F)c2)cn1</smiles><smiles></smiles>

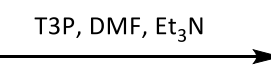
$92 \%$
Scheme 5. Synthetic route employed to prepare an authentic sample of the nilotinib hydroxymethylimidazole metabolite $16 .{ }^{[4]]}$
Scheme 6. Synthetic route employed to prepare an authentic sample of the nilotinib imidazolecarboxylic acid metabolite 17. ${ }^{[42]}$<smiles>CC(=O)c1cn(-c2cc(NC(=O)c3ccc(C)c(Nc4nccc(-c5cccnc5)n4)c3)cc(C(F)(F)F)c2)cn1</smiles> 
substantial levels in the single-dose pharmacokinetic study, it can be concluded that neither the formation nor the activity of metabolites play any role in the efficacy of nilotinib in CML patients.

The relatively weak activity of $\mathbf{1 5}$ compared to that of nilotinib is in accordance with that observed for the imatinib metabolite $\mathbf{5}$, and is attributable to the energy requirement for desolvation not being overcome by any increase in intrinsic binding affinity. However, the finding that $\mathbf{1 6}$ and $\mathbf{1 8}$ are equipotent to nilotinib was unexpected, but in the absence of crystallographic information any rationale for this would be speculative.

\section{Midostaurin}

\subsection{Midostaurin as a Tyrosine Kinase Inhibitor for the Treatment of AML}

Midostaurin (23) is a multi-targeted protein kinase inhibitor which is approved for use in the treatment of both newly-diagnosed FMS-like tyrosine kinase 3 (FLT3)-mutated acute myeloid leukaemia (AML) and stem cell factor receptor kinase (KIT) driven advanced systemic mastocytosis. ${ }^{[43]}$

Although co-crystallization studies with midostaurin are impeded by the poor solubility of the ligand, modelling studies of the drug docked into a homology model of an active conformation of FLT3 indicate that in a crucial interaction, the lactam moiety participates in bidentate hydrogen-bond interactions with backbone amides of the hinge region of the kinase SH1 domain, mimicking the pyrimidine ring of ATP. ${ }^{[44]}$

\subsection{Identification of Metabolites of Midostaurin}

In patients, following the recommended treatment regimen of chronic, twice daily oral administration of $50 \mathrm{mg}$ of midostaurin $\left(\right.$ Rydapt $\left.^{\circledR}\right)$ in gelatin capsules the mean steady-state plasma levels of the drug, the $O$-desmethyl metabolite and a mixture of hydroxylated metabolites (e1 and e2) were 1.25, 2.08 and, for the e1+e2 mixture $9.61 \mu \mathrm{M}$ respectively. ${ }^{[45,46]}$ After a single dose of $50 \mathrm{mg}$ of $\left[{ }^{14} \mathrm{C}\right]$-midostaurin, formulated as a microemulsion drink solution, oral absorption of the drug was high and the average peak plasma concentration of total radioactivity was observed within 3 hours of dosing. ${ }^{[47]}$ Most of the radioactive dose was recovered within 7 days $(81.6 \%)$, primarily in the faeces $(77.6 \%)$, which comprised mainly of metabolites and only $3.4 \%$ of unchanged drug. The main circulating species, expressed as percentage of total area under the plasma drug concentration-time curve $\left(\left[{ }^{14} \mathrm{C}\right] \mathrm{AUC}_{0-96 \mathrm{hr}}\right)$ were unchanged midostaurin $(22.0 \%)$, the $O$-desmethyl metabolite $(27.7 \%)$, e1 $(5.27 \%)$, e2 $(32.7 \%)$ and an epimeric mixture of the hydroxylated $O$-desmethyl metabolite $(7.12 \%)$; a number of minor metabolites accounted for the remaining $5.2 \%$ of the AUC. A large number of metabolites were detected in the faeces, the formation of which was primarily mediated by CYP3A4 $O$-demethylation, pyrrolidinone hydroxylation, phenyl hydroxylation and $\mathrm{N}$-demethylation. The main metabolites found in the urine were benzoic acid and its glycine conjugate, which together represented $2.6 \%$ of the recovered dose (0-72 hours); staurosporine, ${ }^{[44]}$ the other fragment from benzamide cleavage, was not detectable due to the position of the radiolabel (Fig. 5).

Authentic samples of the $O$-desmethyl (24) and the hydroxylated metabolites of midostaurin were synthesised as previously described. ${ }^{[44]}$ The minor metabolite (e1) was confirmed by X-ray crystallography as having 3-S stereochemistry (25); therefore inferring that predominant, hydroxylated metabolite was the $3-R$-stereoisomer (26), authentic samples of 27 have not been prepared (Fig. 5).

\subsection{Effects of Midostaurin Metabolites on Protein Kinases and their Potential Contributions to Drug Efficacy in AML Patients}

Because of the multi-targeted nature of midostaurin and its metabolites, it is difficult to assess the potential contribution of $\mathbf{2 4}$ and $\mathbf{2 6}$ to the clinical efficacy of the drug in patients, but given their high plasma levels achieved upon chronic dosing some effects are very likely. Thus, in biochemical assays at physiologically relevant concentrations, midostaurin itself inhibited 81 of 320 protein kinases with $\mathrm{IC}_{50}$ values $\leq 1 \mu \mathrm{M}$ and the $O$-demethylated metabolite 24 inhibited 75 kinases in the same concentration range. ${ }^{[44]}$ Molecular modelling studies suggest that the presence of the 3-hydroxy group of $\mathbf{2 5}$ and $\mathbf{2 6}$ could in some cases hinder interactions with the hinge region of kinases and, where such hindrance is unlikely, it would lead to reduced kinase activity due to the lack of favourable interactions to overcome desolvation. ${ }^{[44]}$ However in practice, although e2 (26) was generally found to be less potent than midostaurin, it still inhibited 86 kinases with $\mathrm{IC}_{50}$ values $\leq 10 \mu \mathrm{M}$, so given the plasma levels achieved, potential pharmacological effects of this metabolite cannot be discounted.

With respect to the prime targets of midostaurin in its approved indications, 24 inhibits internal tandem duplication (ITD) and D835Y mutated FLT3, as well as D816V KIT with the same potency as the parent drug $\left(\mathrm{IC}_{50}\right.$ values $\left.14-80 \mathrm{nM}\right)$; in contrast
Fig. 5. Main metabolites of midostaurin (23) detected in humans. Structures were proposed based upon mass spectrometry fragmentation and validated by comparison with authentic standards. Thus e1 and e2, were confirmed to be $\mathbf{2 5}$ and $\mathbf{2 6}$, having $3-(S)$ - and 3-(R)-stereochemistry respectively; $\mathbf{2 7}$ is a mixture of epimers. The position of the $\left[{ }^{14} \mathrm{C}\right]$-label in midostaurin used for human adsorption and metabolism studies is indicated by an asterisk.

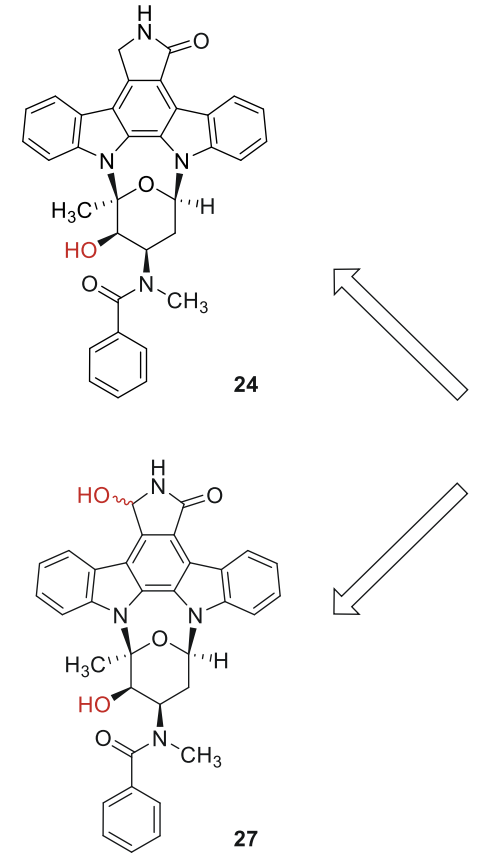

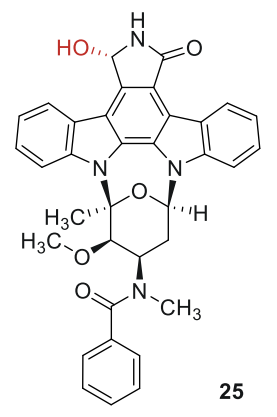

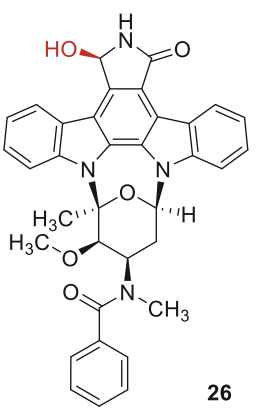


26 is approximately 10 - to 20 -fold less active. ${ }^{[44]}$ With regard to other targets, midostaurin, $\mathbf{2 4}$ and $\mathbf{2 6}$ all potently inhibited both the 3-phosphoinositide-dependent protein kinase 1 (PDPK1) and vascular endothelial growth factor receptor kinase (VEGFR-2) with $\mathrm{IC}_{50}$ values $<100 \mathrm{nM}$. Notably in non-small cell lung cancer cells, Rix and coworkers identified PDPK1, together with TBK1 and AURK-A as major targets of midostaurin. ${ }^{[48,49]}$

Based upon the findings discussed above, attempts to anticipate or correlate the pharmacological properties and pharmacokinetic profile of midostaurin alone with the effects observed in patients are unlikely to be of value, and contributions from the metabolites 24 and 26 need to be taken into consideration.

\section{Summary}

The studies described in this article address the effects of metabolites of three drugs used to treat leukaemia on their respective oncoprotein targets in cells. If drug metabolites achieve adequate levels in the circulation their effects are likely to translate into effects in patients. For example, imatinib is extensively demethylated in some CML patients to the less active, circulating metabolite 7, so that high rates of demethylation might be responsible for inferior responses. In contrast, the second generation drug nilotinib is not subject to extensive metabolism. In the case of midostaurin, two major metabolites accumulate over time and the activity of these might underlie at least some of the efficacy manifested in AML patients: this also illustrates a limitation of single-dose drug metabolism studies which do not detect metabolite accumulation. The efficacy of drugs is also related to the ability of the patient to tolerate adverse events at the doses administered and, particularly because of polypharmacologies, metabolites might be associated with more severe or different off-target effects than the parent drug: this latter aspect is not addressed in the present study.

An understanding of the binding modes of drugs is useful for predicting the activity of putative metabolites against the target protein and, where metabolic deactivation is to be expected, strategies can be considered to mitigate the formation of such metabolites. Thus in the case of imatinib, in an attempt to reduce conversion to the $N$-desmethylpiperazine metabolite 7, both the $\mathrm{N}$-ethyl and $\mathrm{N}$-deuteromethyl imatinib analogues were evaluated, although following the discovery of nilotinib neither of these strategies were pursued. ${ }^{[22,50]}$ Although neither $\mathbf{5}$ nor $\mathbf{1 5}$ were major metabolites of imatinib or nilotinib, a potential strategy to mitigate the oxidation of the phenyl- $\mathrm{CH}_{3}$ moieties would be to replace the methyl group with a halogen atom. In the case of nilotinib the 4-fluorobenzamide analogue (prepared by reacting 21 with 4-fluoro-3-nitrobenzoyl chloride, followed by elaboration in a manner analogous to that in Scheme 4) was less active (32D cell $\left.\mathrm{GI}_{50} 149 \pm 17 \mathrm{nM}\right)$. The activity observed for the aniline 18 against BCR-ABL1 suggests that this compound exploits different binding interactions to those of nilotinib (18 is also more potent than nilotinib against KIT autophosphorylation in the GIST882 gastrointestinal stomal tumour cell line), ${ }^{[51]}$ however exploiting this with a molecule designed to have the amine as an unmasked pharmacophore element would not be without liabilities.

In conclusion, studies such as these contribute to our understanding of the potential roles of metabolites in drug efficacy and can provide useful information for preclinical drug discovery activities to find new therapeutics.

\section{Acknowledgements}

I wish to acknowledge the mentoring and encouragement provided by Professors Alex Matter (Novartis Pharma AG) and James D. Griffin (Dana-Farber Cancer Institute, Boston, MS). Markus Gaugler is thanked for his skilled practical work in preparing authentic samples of metabolites, together with Dr. Jürgen Mestan and his team for measuring their effects on cellular BCR-ABL1 kinase activity.

Received: May 10, 2019
[1] R. S. Obach. Pharmacol. Rev. 2013, 65, 578.

[2] W. G. Humphreys, 'Pharmacological and Toxicological Activity of Drug Metabolites' in 'ADME-Enabling Technologies in Drug Design and Development', Ed. D. Zhang, John Wiley \& Sons, Inc., 2012

[3] A. Parkinson, B. W. Ogilvie, B. L. Paris, T. N. Hensley, G. J. Loewen, 'Human Biotransformation' in 'Biotransformation and Metabolite Elucidation of Xenobiotics', Ed. A. F. Nassar, John Wiley \& Sons, Inc., 2010.

[4] A. Fura, Drug Discovery Today 2006, 11, 133.

[5] S. Schadt, B. Bister, S. K. Chowdhury, C. Funk, C. E. Hop, W. G. Humphreys, F. Igarashi, A. D. James, M. Kagan, S. C. Khojasteh, A. N. Nedderman, C. Prakash, F. Runge, H. Scheible, D. K. Spracklin, P. Swart, S. Tse, J. Yuan, R. S. Obach, Drug Metab. Dispos. 2018, 46, 865.

[6] P. W. Manley, P. Holzer, H. Möbitz, P. R. Skaanderup, F. Stauffer, 'Progress into the Era of Genomically Targeted Cancer Drugs: 50 years of Anticancer Medicinal Chemistry' in '2015 Medicinal Chemistry Reviews', Ed. M. C. Desai, American Chemical Society, 2015.

[7] P. W. Manley, N. Stiefl, S. W. Cowan-Jacob, S. Kaufman, J. Mestan, M. Wartmann, M. Wiesmann, R. Woodman, N. Gallagher, Bioorg. Med. Chem. Lett. 2010, 18, 6977.

[8] P. W. Manley, N. J. Stiefl, 'Progress in the Discovery of BCR-ABL Kinase Inhibitors for the Treatment of Leukemia' in 'Topics in Medicinal Chemistry', Ed. M. J. Waring, Springer International Publishing AG, 2017.

[9] T. Schindler, W. Bornmann, P. Pellicena, W. T. Miller, B. Clarkson, J. Kuriyan, Science 2000, 289, 1938.

[10] B. Nagar, W. G. Bornmann, P. Pellicena, T. Schindler, D. R. Veach, W. T. Miller, B. Clarkson, J. Kuriyan, Cancer Res. 2002, 62, 4236.

[11] S. W. Cowan-Jacob, G. Fendrich, A. Floersheimer, P. Furet, J. Liebetanz, G. Rummel, P. Rheinberger, M. Centeleghe, D. Fabbro, P. W. Manley, Acta Cryst. 2007, 63, 80 .

[12] N. Vajpai, A. Strauss, G. Fendrich, S. W. Cowan-Jacob, P. W. Manley, S. Grzesiek, W. Jahnke J. Biol. Chem. 2008, 283, 18292.

[13] R. A. Larson, B. J. Druker, F. Guilhot, S. G. O'Brien, G. J. Riviere, T. Krahnke, I. Gathmann, Y. Wang, Blood 2008, 111, 4022.

[14] B. Peng, P. Lloyd, H. Schran, Clin. Pharmacokinet. 2005, 44, 879.

[15] N. Nebot, S. Crettol, F. d'Esposito, B. Tattam, D. E. Hibbs, M. Murray, Br. J. Pharmacol. 2010, 161, 1059.

[16] H. Gschwind, U. Pfaar, F. Waldmeier, M. Zollinger, C. Sayer, P. Zbinden, M. Hayes, R. Pokorny, M. Seiberling, M. Benam, B. Peng, Drug Met. Disp. 2005, 33, 1503 .

[17] M.p. $226-227{ }^{\circ} \mathrm{C}(\mathrm{EtOH}) .{ }^{1} \mathrm{H}-\mathrm{NMR}\left(600 \mathrm{MHz}, \mathrm{DMSO}-\mathrm{d}_{6}\right): \delta 10.20$ (s, 1H), $9.27(\mathrm{~d}, \mathrm{~J}=2.3 \mathrm{~Hz}, 1 \mathrm{H}), 9.01(\mathrm{~s}, 1 \mathrm{H}), 8.68(\mathrm{dd}, \mathrm{J}=4.7,1.6 \mathrm{~Hz}, 1 \mathrm{H}), 8.55-$ $8.43(\mathrm{~m}, 2 \mathrm{H}), 8.07(\mathrm{~d}, \mathrm{~J}=2.2 \mathrm{~Hz}, 1 \mathrm{H}), 7.91(\mathrm{~d}, \mathrm{~J}=7.9 \mathrm{~Hz}, 2 \mathrm{H}), 7.58-7.40$ $(\mathrm{m}, 5 \mathrm{H}), 7.20(\mathrm{~d}, \mathrm{~J}=8.4 \mathrm{~Hz}, 1 \mathrm{H}), 3.61(\mathrm{~s}, 2 \mathrm{H}), 3.03(\mathrm{~s}, 3 \mathrm{H}), 2.83(\mathrm{t}, \mathrm{J}=11.2$ $\mathrm{Hz}, 4 \mathrm{H}), 2.53$ (s, 3H), $2.22(\mathrm{~s}, 3 \mathrm{H})$.

[18] M.p. 242-244 ${ }^{\circ} \mathrm{C}\left(\mathrm{CH}_{2} \mathrm{Cl}_{2}-\mathrm{MeOH}\right) .{ }^{1} \mathrm{H}-\mathrm{NMR}$ (600 MHz, DMSO-d6): $\delta$ $10.25(\mathrm{~s}, 1 \mathrm{H}), 9.28(\mathrm{~d}, \mathrm{~J}=2.2 \mathrm{~Hz}, 1 \mathrm{H}), 8.99(\mathrm{~s}, 1 \mathrm{H}), 8.68(\mathrm{dd}, \mathrm{J}=4.8,1.7$ $\mathrm{Hz}, 1 \mathrm{H}), 8.51(\mathrm{~d}, \mathrm{~J}=5.1 \mathrm{~Hz}, 1 \mathrm{H}), 8.48(\mathrm{dt}, \mathrm{J}=8.0,2.0 \mathrm{~Hz}, 1 \mathrm{H}), 8.08(\mathrm{~d}, \mathrm{~J}=$ $2.2 \mathrm{~Hz}, 1 \mathrm{H}), 7.93(\mathrm{~d}, \mathrm{~J}=8.0 \mathrm{~Hz}, 2 \mathrm{H}), 7.79(\mathrm{~d}, \mathrm{~J}=8.2 \mathrm{~Hz}, 2 \mathrm{H}), 7.52(\mathrm{dd}, \mathrm{J}=$ $8.0,4.8 \mathrm{~Hz}, 1 \mathrm{H}), 7.48(\mathrm{dd}, \mathrm{J}=8.2,2.2 \mathrm{~Hz}, 1 \mathrm{H}), 7.43(\mathrm{~d}, \mathrm{~J}=5.1 \mathrm{~Hz}, 1 \mathrm{H}), 7.21$ $(\mathrm{d}, \mathrm{J}=8.4 \mathrm{~Hz}, 1 \mathrm{H}), 4.48(\mathrm{~s}, 2 \mathrm{H}), 4.12-3.94(\mathrm{~m}, 4 \mathrm{H}), 3.10(\mathrm{~s}, 3 \mathrm{H}), 2.85(\mathrm{~d}, \mathrm{~J}$ $=9.1 \mathrm{~Hz}, 2 \mathrm{H}), 2.72(\mathrm{~d}, \mathrm{~J}=8.9 \mathrm{~Hz}, 2 \mathrm{H}), 2.22(\mathrm{~s}, 3 \mathrm{H})$.

[19] K. O. Börnsen, P. End, G. Gross, U. Pfaar, P. W. Manley, J. Zimmermann, US Patent Appl. No. US 2010/0222362, 2010.

[20] M.p. $254-255^{\circ} \mathrm{C}(\mathrm{MeOH}) .{ }^{1} \mathrm{H}-\mathrm{NMR}\left(600 \mathrm{MHz}, \mathrm{DMSO}-\mathrm{d}_{6}\right): \delta 10.19(\mathrm{~s}, 1 \mathrm{H})$, $9.10(\mathrm{~s}, 1 \mathrm{H}), 8.85(\mathrm{~s}, 1 \mathrm{H}), 8.55(\mathrm{~d}, \mathrm{~J}=5.0 \mathrm{~Hz}, 1 \mathrm{H}), 8.33(\mathrm{~d}, \mathrm{~J}=6.4 \mathrm{~Hz}, 1 \mathrm{H})$, 8.13-8.00 (m, 2H), $7.91(\mathrm{~d}, \mathrm{~J}=7.9 \mathrm{~Hz}, 2 \mathrm{H}), 7.59-7.47(\mathrm{~m}, 2 \mathrm{H}), 7.44(\mathrm{dd}, \mathrm{J}$ $=9.4,6.5 \mathrm{~Hz}, 3 \mathrm{H}), 7.21(\mathrm{~d}, \mathrm{~J}=8.2 \mathrm{~Hz}, 1 \mathrm{H}), 3.52(\mathrm{~s}, 2 \mathrm{H}), 2.35(\mathrm{~s}, 6 \mathrm{H}), 2.21$ $(\mathrm{s}, 3 \mathrm{H}), 2.15(\mathrm{~s}, 3 \mathrm{H})$.

[21] J. Zimmermann, E. Buchdunger, H. Mett, T. Meyer, N. B. Lydon, P. Traxler, Bioorg. Med. Chem. Lett. 1996, 6, 1221.

[22] P. W. Manley, F. Blasco, J. Mestan, R. Aichholz, Bioorg. Med. Chem. 2013, 21,3231 .

[23] M.p. > $140{ }^{\circ} \mathrm{C}$ (decomp.; MeOH). ${ }^{1} \mathrm{H}-\mathrm{NMR}(500 \mathrm{MHz}, \mathrm{DMSO}-\mathrm{d} 6): \delta$ $10.18(\mathrm{~s}, 1 \mathrm{H}), 9.26(\mathrm{~d}, \mathrm{~J}=1.98 \mathrm{~Hz}, 1 \mathrm{H}), 8.99(\mathrm{~s}, 1 \mathrm{H}), 8.67(\mathrm{dd}, \mathrm{J}=4.73$, $1.53 \mathrm{~Hz}, 1 \mathrm{H}), 8.50(\mathrm{~d}, \mathrm{~J}=5.04 \mathrm{~Hz}, 1 \mathrm{H}), 8.47(\mathrm{~m} .1 \mathrm{H}), 8.06(\mathrm{~s}, 1 \mathrm{H}), 7.91$ $(\mathrm{d}, \mathrm{J}=8.09,1 \mathrm{H}), 7.51(\mathrm{dd}, \mathrm{J}=7.93,4.73 \mathrm{~Hz}, 1 \mathrm{H}), 7.46(\mathrm{~m}, 3 \mathrm{H}), 7.42$ $(\mathrm{d}, \mathrm{J}=5.19 \mathrm{~Hz}, 1 \mathrm{H}), 7.19(\mathrm{~d}, \mathrm{~J}=8.39 \mathrm{~Hz}, 1 \mathrm{H}), 3.60(\mathrm{~s}, 2 \mathrm{H}), 3.26(\mathrm{t}, \mathrm{J}=$ $5.42 \mathrm{~Hz}, 2 \mathrm{H}), 2.96(\mathrm{~s}, 2 \mathrm{H}), 2.80(\mathrm{~s}, 3 \mathrm{H}), 2.63(\mathrm{t}, \mathrm{J}=5.49 \mathrm{~Hz}, 2 \mathrm{H}), 2.21$ (s, $3 \mathrm{H})$.

[24] M.p. 196-198 ${ }^{\circ} \mathrm{C}$ (MeOH-EtOAc). ${ }^{1} \mathrm{H}-\mathrm{NMR}\left(500 \mathrm{MHz}, \mathrm{DMSO}-\mathrm{d}_{6}\right) \delta 2.14$ $(\mathrm{s}, 3 \mathrm{H}), 2.25-2.45(\mathrm{~m}, 8 \mathrm{H}), 3.52(\mathrm{~s}, 2 \mathrm{H}), 4.56(\mathrm{~s}, 2 \mathrm{H}), 5.50$ (brs, $1 \mathrm{H}), 7.29$ $(\mathrm{d}, \mathrm{J}=8.3 \mathrm{~Hz}, 1 \mathrm{H}), 7.41(\mathrm{dd}, \mathrm{J}=2.0,8.3 \mathrm{~Hz}, 1 \mathrm{H}), 7.44(\mathrm{~d}, \mathrm{~J}=8.1 \mathrm{~Hz}, 2 \mathrm{H})$, $7.50(\mathrm{~d}, \mathrm{~J}=5.1 \mathrm{~Hz}, 1 \mathrm{H}), 7.52(\mathrm{dd}, \mathrm{J}=3.3,8.1 \mathrm{~Hz}, 1 \mathrm{H}), 7.93(\mathrm{~d}, \mathrm{~J}=8.1 \mathrm{~Hz}$ $2 \mathrm{H}), 8.56(\mathrm{~d}, \mathrm{~J}=2.0 \mathrm{~Hz}, 1 \mathrm{H}), 8.57(\mathrm{~d}, \mathrm{~J}=5.1 \mathrm{~Hz}, 1 \mathrm{H}), 8.59$ (ddd, $\mathrm{J}=1.4$, $2.1,8.1 \mathrm{~Hz}, 1 \mathrm{H}), 8.69(\mathrm{dd}, \mathrm{J}=1.4,3.3 \mathrm{~Hz}, 1 \mathrm{H}), 9.10(\mathrm{~s}, 1 \mathrm{H}), 9.33(\mathrm{~d}, \mathrm{~J}=2.1$ $\mathrm{Hz}, 1 \mathrm{H})$ and $10.22(\mathrm{~s}, 1 \mathrm{H})$.

[25] F.D.A. Center for Drug Evaluation and Research; http://www.accessdata. fda.gov/drugsatfda_docs/nda/2001/21-335_Gleevec_pharmr_P2.pdf.

[26] M. J. Eck, P. W. Manley, Current Opin. Cell Biol. 2009, 21, 288.

[27] P. W. Manley, S. W. Cowan-Jacob, J. Mestan, Biochim. Biophys. Acta 2005, 1754, 3 . 
[28] P. W. Manley, P. Drueckes, G. Fendrich, P. Furet, J. Liebetanz, G. MartinyBaron, J. Mestan, J. Trappe, M. Wartmann, D. Fabbro. Biochim. Biphys. Acta 2010, 1804, 445.

[29] B. E. Houk, C. L. Bello, D. Kang, M, Amantea, Clin. Cancer Res. 2009, 15, 2497.

[30] E. Weisberg, P. W. Manley, W. Breitenstein, J. Brueggen, S. W. Cowan-Jacob, A. Ray, B. Huntly, D. Fabbro, G. Fendrich, E. Hall-Meyers, A. L. Kung, J. Mestan, G. Q. Daley, L. Callahan, L. Catley, C. Cavazza, A. Mohammed, D. Neuberg, R. D. Wright, D. G. Gilliland, G. D. Griffin, Cancer Cell 2005, 7, 129.

[31] P.W. Manley, S.W. Cowan-Jacob, G. Fendrich, J. Mestan. Blood 2005, 106, 940a.

[32] J. A. Olsen, D. W. Banner, P. Seiler, B. Wagner, T. Tschopp, U. Obst-Sander, M. Kansy, K. Müller, F. Diederich, ChemBioChem 2004, 5, 666.

[33] X. Tian, H. Zhang, T. Heimbach, H. He, A. Buchbinder, M. Aghoghovbia, F. Hourcade-Potelleret, J. Clin. Pharmacol. 2018, 58, 1533.

[34] F.D.A. Center for Drug Evaluation and Research; http://www.accessdata. fda.gov/drugsatfda docs/nda/2007/022068s000 ClinPharmR.pdf.

[35] M.p. 282-287 ${ }^{\circ} \mathrm{C} ;{ }^{1} \mathrm{H}$ NMR (400 MHz; DMSO-d $) \delta 2.17$ (s, 3H), 2.33 (s, $3 \mathrm{H}), 7.45(\mathrm{~m}, 1 \mathrm{H}), 7.50(\mathrm{dd}, \mathrm{J}=7.96,6.44 \mathrm{~Hz}, 1 \mathrm{H}), 7.69(\mathrm{~s}, 1 \mathrm{H}), 7.76(\mathrm{dd}$, $\mathrm{J}=7.96,1.64 \mathrm{~Hz}, 1 \mathrm{H}), 7.97(\mathrm{~d}, \mathrm{~J}=8.34 \mathrm{~Hz}, 1 \mathrm{H}), 8.11(\mathrm{~s}, 1 \mathrm{H}), 8.18(\mathrm{~d}, \mathrm{~J}=$ $1.26 \mathrm{~Hz}, 1 \mathrm{H}), 8.21(\mathrm{~d}, \mathrm{~J}=1.26 \mathrm{~Hz}, 1 \mathrm{H}), 8.28(\mathrm{~m}, 1 \mathrm{H}), 8.55(\mathrm{~s}, 1 \mathrm{H}), 8.79(\mathrm{~s}$, $1 \mathrm{H}), 9.24(\mathrm{~s}, 1 \mathrm{H}), 10.57(\mathrm{~s}, 1 \mathrm{H})$.

[36] M.p. 302-307 ${ }^{\circ} \mathrm{C}$; ${ }^{1} \mathrm{H}$ NMR (600 MHz; DMSO-d $) \delta 2.18$ (s, 3H), 2.41 (s, $3 \mathrm{H}), 7.44(\mathrm{dd}, \mathrm{J}=7.77,4.94 \mathrm{~Hz}, 1 \mathrm{H}), 7.51(\mathrm{~s}, 1 \mathrm{H}), 7.55(\mathrm{~d}, \mathrm{~J}=7.87 \mathrm{~Hz}, 1 \mathrm{H})$, $7.69(\mathrm{~d}, \mathrm{~J}=6.66 \mathrm{~Hz}, 1 \mathrm{H}), 7.74(\mathrm{~s}, 1 \mathrm{H}), 7.83(\mathrm{~d}, \mathrm{~J}=7.67 \mathrm{~Hz}, 1 \mathrm{H}), 8.18(\mathrm{~s}$ $1 \mathrm{H}), 8.23(\mathrm{~s}, 1 \mathrm{H}), 8.31(\mathrm{~s}, 1 \mathrm{H}), 8.41(\mathrm{~d}, \mathrm{~J}=7.87 \mathrm{~Hz}, 1 \mathrm{H}), 8.59(\mathrm{~d}, \mathrm{~J}=4.64$ $\mathrm{Hz}, 1 \mathrm{H}), 8.69(\mathrm{~s}, 1 \mathrm{H}), 8.78(\mathrm{~d}, \mathrm{~J}=6.66 \mathrm{~Hz}, 1 \mathrm{H}), 9.27(\mathrm{~s}, 1 \mathrm{H}), 9.89$ (br s, $1 \mathrm{H})$, $10.73(\mathrm{~s}, 1 \mathrm{H})$.

[37] M.p. 316-320 ${ }^{\circ} \mathrm{C} ;{ }^{1} \mathrm{H}$ NMR (400 MHz; DMSO-d $) \delta 2.17$ (s, 3H), 2.36 (s, $3 \mathrm{H}), 7.43(\mathrm{dd}, \mathrm{J}=8.02,6.57 \mathrm{~Hz}, 1 \mathrm{H}), 7.48(\mathrm{~d}, \mathrm{~J}=1.07 \mathrm{~Hz}, 1 \mathrm{H}), 7.52(\mathrm{~d}, \mathrm{~J}=$ $8.15 \mathrm{~Hz}, 1 \mathrm{H}), 7.64(\mathrm{~d}, \mathrm{~J}=6.69 \mathrm{~Hz}, 1 \mathrm{H}), 7.70(\mathrm{~s}, 1 \mathrm{H}), 7.84(\mathrm{dd}, \mathrm{J}=7.86,1.74$ $\mathrm{Hz}, 1 \mathrm{H}), 7.90(\mathrm{~d}, \mathrm{~J}=8.97 \mathrm{~Hz}, 1 \mathrm{H}), 8.12(\mathrm{~s}, 1 \mathrm{H}), 8.19(\mathrm{~d}, \mathrm{~J}=1.39 \mathrm{~Hz}, 1 \mathrm{H})$, $8.21(\mathrm{~m}, 1 \mathrm{H}), 8.30(\mathrm{~d}, \mathrm{~J}=1.39 \mathrm{~Hz}, 1 \mathrm{H}), 8.46(\mathrm{~d}, \mathrm{~J}=1.64 \mathrm{H}, 1 \mathrm{H}), 8.70(\mathrm{t}, \mathrm{J}=$ $1.45 \mathrm{~Hz}, 1 \mathrm{H}), 8.74(\mathrm{~d}, \mathrm{~J}=6.63 \mathrm{~Hz}, 1 \mathrm{H}), 9.89(\mathrm{~s}, 1 \mathrm{H}), 10.66(\mathrm{~s}, 1 \mathrm{H})$.

[38] M.p. $273-276{ }^{\circ} \mathrm{C} ;{ }^{1} \mathrm{H}$ NMR (600 MHz DMSO-d $) \delta 2.18(\mathrm{~s}, 3 \mathrm{H}), 4.69$ (d, J = $5.05 \mathrm{~Hz}, 2 \mathrm{H}), 5.70(\mathrm{t}, \mathrm{J}=5.25 \mathrm{~Hz}, 1 \mathrm{H}), 7.46-7.52(\mathrm{~m}, 2 \mathrm{H}), 7.56(\mathrm{~d}, \mathrm{~J}=5.05$ $\mathrm{Hz}, 1 \mathrm{H}), 7.59(\mathrm{~d}, \mathrm{~J}=8.07 \mathrm{~Hz}, 1 \mathrm{H}), 7.74(\mathrm{~s}, 1 \mathrm{H}), 7.76(\mathrm{~d}, \mathrm{~J}=8.07 \mathrm{~Hz}, 1 \mathrm{H})$, $8.17(\mathrm{~s}, 1 \mathrm{H}), 8.22(\mathrm{~s}, 1 \mathrm{H}), 8.31(\mathrm{~s}, 1 \mathrm{H}), 8.50(\mathrm{~d}, \mathrm{~J}=8.07 \mathrm{~Hz}, 1 \mathrm{H}), 8.60(\mathrm{~d}, \mathrm{~J}$ $=5.05 \mathrm{~Hz}, 1 \mathrm{H}), 8.66(\mathrm{br} \mathrm{s}, 1 \mathrm{H}), 8.68(\mathrm{~d}, \mathrm{~J}=4.64 \mathrm{~Hz}, 1 \mathrm{H}), 9.29(\mathrm{~s}, 1 \mathrm{H}), 9.34$ (s, 1H), $10.69(\mathrm{~s}, 1 \mathrm{H})$.

[39] M.p. 278-279 ${ }^{\circ} \mathrm{C} ;{ }^{1} \mathrm{H}$ NMR (400 MHz DMSO-d ) $\delta 2.32$ (s, 3H), 7.35 (d, J = $8.06 \mathrm{~Hz}, 1 \mathrm{H}), 7.43-7.56(\mathrm{~m}, 2 \mathrm{H}), 7.62(\mathrm{dd}, \mathrm{J}=7.82,1.71 \mathrm{~Hz}, 1 \mathrm{H}), 8.23-8.33$ (m, 1H), 8.40-8.57 (m, 2H), $8.69(\mathrm{dd}, \mathrm{J}=4.76,1.71 \mathrm{~Hz}, 1 \mathrm{H}), 9.06(\mathrm{~s}, 1 \mathrm{H})$, $9.27(\mathrm{~d}, \mathrm{~J}=1.59 \mathrm{~Hz}, 1 \mathrm{H}), 12.83$ (br s, $1 \mathrm{H})$

[40] M.p. $>221{ }^{\circ} \mathrm{C}$ (sublimed; hexane-EtOAc). ${ }^{1} \mathrm{H}-\mathrm{NMR}\left(600 \mathrm{MHz}, \mathrm{DMSO}_{6}\right.$ ) $\delta 2.34(\mathrm{~s}, 3 \mathrm{H}), 5.64(\mathrm{br} \mathrm{s}, 2 \mathrm{H}), 6.59(\mathrm{~s}, 1 \mathrm{H}), 7.25(\mathrm{~s}, 1 \mathrm{H}), 7.41(\mathrm{~d}, \mathrm{~J}=8.0$ $\mathrm{Hz}, 2 \mathrm{H}), 7.48(\mathrm{~d}, \mathrm{~J}=5.1 \mathrm{~Hz}, 1 \mathrm{H}), 7.52(\mathrm{dd}, \mathrm{J}=8.0,4.8 \mathrm{~Hz}, 1 \mathrm{H}), 7.71$ (dd, J $=7.9,1.9 \mathrm{~Hz}, 1 \mathrm{H}), 8.24(\mathrm{~d}, \mathrm{~J}=1.9 \mathrm{~Hz}, 1 \mathrm{H}), 8.45(\mathrm{dt}, \mathrm{J}=8.0,2.1 \mathrm{~Hz}, 1 \mathrm{H})$, $8.55(\mathrm{~d}, \mathrm{~J}=5.2 \mathrm{~Hz}, 1 \mathrm{H}), 8.69(\mathrm{dd}, \mathrm{J}=4.8,1.6 \mathrm{~Hz}, 1 \mathrm{H}), 9.16(\mathrm{~s}, 1 \mathrm{H}), 9.27$ $(\mathrm{d}, \mathrm{J}=2.2,1 \mathrm{H}), 10.16(\mathrm{~s}, 1 \mathrm{H})$

[41] M.p. 257-260 ${ }^{\circ} \mathrm{C}$; ${ }^{1} \mathrm{H}$ NMR (400 MHz DMSO-d $) \delta 2.36$ (s, 3H), 4.42 $(\mathrm{d}, \mathrm{J}=5.5 \mathrm{~Hz}, 2 \mathrm{H}), 5.06-4.93(\mathrm{~m}, 1 \mathrm{H}), 7.53-7.39(\mathrm{~m}, 3 \mathrm{H}), 7.58(\mathrm{~s}, 1 \mathrm{H})$, $7.81-7.69(\mathrm{~m}, 2 \mathrm{H}), 8.16(\mathrm{~s}, 1 \mathrm{H}), 8.25(\mathrm{~s}, 1 \mathrm{H}), 8.31(\mathrm{~s}, 2 \mathrm{H}), 8.43(\mathrm{~d}, \mathrm{~J}=8.0$ $\mathrm{Hz}, 1 \mathrm{H}), 8.53(\mathrm{~d}, \mathrm{~J}=5.1 \mathrm{~Hz}, 1 \mathrm{H}), 8.66(\mathrm{~d}, \mathrm{~J}=4.7 \mathrm{~Hz}, 1 \mathrm{H}), 9.14(\mathrm{~s}, 1 \mathrm{H})$ $9.26(\mathrm{~d}, \mathrm{~J}=2.3 \mathrm{~Hz}, 1 \mathrm{H}), 10.58(\mathrm{~s}, 1 \mathrm{H})$.

[42] M.p. > $286{ }^{\circ} \mathrm{C}$ (decomp.); ${ }^{1} \mathrm{H}$ NMR (400 MHz DMSO-d $) ~ \delta 2.35$ (s, 3H), $7.43(\mathrm{~d}, \mathrm{~J}=8.34 \mathrm{~Hz}, 1 \mathrm{H}), 7.46(\mathrm{~d}, \mathrm{~J}=5.18 \mathrm{~Hz}, 1 \mathrm{H}), 7.48(\mathrm{ddd}, \mathrm{J}=7.99$, 4.77, $0.82 \mathrm{~Hz}, 1 \mathrm{H}), 7.74(\mathrm{dd}, \mathrm{J}=7.89,1.89 \mathrm{~Hz}, 1 \mathrm{H}), 7.86(\mathrm{t}, \mathrm{J}=1.48 \mathrm{~Hz}$, $1 \mathrm{H}), 8.22(\mathrm{t}, \mathrm{J}=1.48 \mathrm{~Hz}, 1 \mathrm{H}), 8.32(\mathrm{~d}, \mathrm{~J}=1.83 \mathrm{~Hz}, 1 \mathrm{H}), 8.36-8.37(\mathrm{~m}$, $1 \mathrm{H}), 8.37(\mathrm{~d}, 1 \mathrm{H}), 8.38(\mathrm{~d}, 1 \mathrm{H}), 8.42(\mathrm{ddd}, \mathrm{J}=8.02,2.24,1.74 \mathrm{~Hz}, 1 \mathrm{H})$, $8.52(\mathrm{~d}, \mathrm{~J}=5.12 \mathrm{~Hz}, 1 \mathrm{H}), 8.65(\mathrm{dd}, \mathrm{J}=4.74,1.64 \mathrm{~Hz}, 1 \mathrm{H}), 9.13(\mathrm{~s}, 1 \mathrm{H})$, $9.25(\mathrm{dd}, \mathrm{J}=2.31,0.79 \mathrm{~Hz}, 1 \mathrm{H}), 10.62(\mathrm{~s}, 1 \mathrm{H})$.

[43] R. M. Stone, P. W. Manley, R. A. Larson, R. Capdeville, Blood Adv. 2018 $2,444$.

[44] P. W. Manley, G. Caravatti, P. Furet, J. Roesel, P. Tran, T. Wagner, M. Wartmann, Biochemistry 2018, 57, 5576

[45] T. Illmer, H. M. Thiede, C. Thiede., M. Bornhaeuser, M. Schaich, E. Schleyer, G. Ehninger, J. Pharmacol. Toxicol. Methods 2007, 56, 23.

[46] T. Fischer, R. M. Stone, D. J. DeAngelo, I. Galinsky, E. Estey, C. Lanza, E. Fox, G. Ehninger, E. J. Feldman, G. J. Schiller, V. M. Klimek, S. D. Nimer, D. G. Gilliland, C. Dutreix, A. Huntsman-Labed, J. Virkus, F. J. Giles, J. Clin. Oncol. 2010, 28, 4339.

[47] H. He, P. Tran, H. Gu, V. Tedesco, J. Zhang, W. Lin, E. Gatlik, K. Klein, T. Heimbach, Drug Metab. Dispos. 2017, 45, 540.

[48] C. Ctortecka, V. Palve, B. M. Kuenzi, B. Fang, N. J. Sumi, V. Izumi, S. Novakova, F. Kinose, L. L. R. Rix, E. B. Haura, J. M. Koomen, U. Rix, Mol. Cell Proteomics 2018, 17, 2434.

[49] In ref. [44] the serine-threonine TANK-binding kinase 1 (TBK1) was wrongly labelled as TKB1. The activity of midostaurin against TBK-1 is discussed in some detail in ref. [48].

[50] H. M. Buerger, G. Caravatti, J. Zimmermann, P. W. Manley, W. Breitenstein, M. A. Cudd. US Patent Appl. No. US 2004/0102453, 2010.

[51] P. W. Manley, J. Mestan, J. Sheng, P. Tran, M. Kagan. Blood 2013, 122, 4011. 